\title{
INVESTIGATION OF THE CURRENT SPACE VECTOR CORRECTION OF 3P3W VOLTAGE INVERTER
}

\begin{abstract}
The article presents a solution to the problem of asymmetry of a three-phase voltage inverter output currents for the trajectory correction vector currents to a wheel form. The solution uses the layout described using the fuzzy logic equations. Test results apply to verify a system operation in terms of the asymmetric load. It was examined in the form of a circular trajectory of the vector output currents in case of resistant or induction asymmetry. Also not harmonics components of load currents are included. They simulate the vibrations of mechanical loads or mechanical resonance. After verification by simulations the laboratory prototype control system of inverter with equalizer in the FPGA was performed. The investigations were done on the system created for this purpose, using the field programmable gate arrays of EP3SL150F type. This system performs the task of correcting space vector of the inverter currents and, at the same time, the process of modulation waveforms. In parallel with the controlling tasks the inverter model was running in real time. The waveforms of inverter model were observed using a Signal Tap II utility or after processing into an analog signal using an oscilloscope. Observed trajectories of the currents' space vector were adjusted to the circular form in addition to the type of load asymmetry.
\end{abstract}

Keywords: space vector, voltage inverter, corrector, fuzzy logic

\section{Introduction}

The three-phase three wire voltage inverter is one of the most commonly used converters in power electronics. Its topology is used in a number of areas requiring transformation of DC power to AC power in three phase circuits. The most common area of the voltage inverter uses is integrated with inductive motors operation in almost every industry, beginning from power engineering with motor vehicles ending [1]. There are many methods of the inverter output waveform modulation. The simplest one is the natural modulation.

${ }^{1}$ Tomasz Binkowski, Katedra Energoelektroniki i Elektroenergetyki, Politechnika Rzeszowska, ul. W. Pola 2, 35-959 Rzeszów, tbinkow@ prz.edu.pl 
However, it has limitations in terms of an amplitude modulating function limitation in relation to the current waveforms, which results in an additional frequency components occurring as output currents deformation. It comes then to the overmodulation [2]. A larger, maximum voltage boost voltage inverter is obtained by applying a vector modulation. This modulation is widely used due to its ability to inflict the values directly in the orthographic reference system [3]. Implementation of the 3P3W inverter involves the realization of complex calculations arising out of the control process. Commonly the processors are used for this purpose, often specially optimized for control tasks and performing control using digital machines [4-5]. However, control processes and the complexity of additional operations to be performed in parallel (for example verification of real-time models) are so complicated, that they require a different approach in the implementation of their hardware platform [6]. A family of such systems are programmable logic of FPGA, that allow the parallel operation of main tasks. These systems are increasingly used in the power converters control [7]. One of the objectives of the control strategy is getting the symmetric sine waveform of an output current. Such waves, in most cases of control, are achieved for symmetric load and symmetric control. Load asymmetries resulting from changes of the resistance-induction parameters or other external impacts, effect on changing the trajectory of the currents space vector. To limit the impact of asymmetric load the corrector of current trajectory can be attached to the modulation process. The case of the space vector correction application was described in literature [8]. There has been shown that it is possible to correct the trajectory of the output currents space vector of a voltage inverter. A solution presented in [8] relates to the use of the fuzzy logic system. Application of the corrector resulted in a circular trajectory of currents, but at the same time the load currents were no sinusoidal. The study shows how to eliminate no sinusoidal waves of the inverter output currents while maintaining their circular trajectory in terms of asymmetry.

\section{Equalizer circuit in the inverter control process}

The corrector of the vector output currents main task is to adjust the space vector currents to preset, fixed values. This value is the reference value from the other levels of regulatory process. Changes in the physical length of the space vector output currents of the voltage inverter result from the changes of the control process, or due to asymmetry of load in the case of symmetrical control. Symmetrical control refers to one of the known ways of modulation of the inverter output waveform, where modulation functions are sinusoidal and symmetrical. The case under consideration in the article refers to the case of three phase waveforms of the natural modulation in the 3-wire inverter. The deformations of the current vector trajectory resulting from the asymmetry of a load are adjusted 
by the appropriate modification of modulation functions. A general diagram of the inverter with the corrector is shown in figure 1. In a considered topology of the inverter a block that represents the source of DC voltage is distinguished. During the case of analysis the source DC voltage without deformation is taken into consideration. In case of general it may be the DC-link circuit, where in addition to the constant component the variable components are as a ripple. Ripple may result from inverter power supply from the single phase source. Then the primary component will have a ripple frequency of twice the value of a single phase source frequency. This is not discussed in the study.

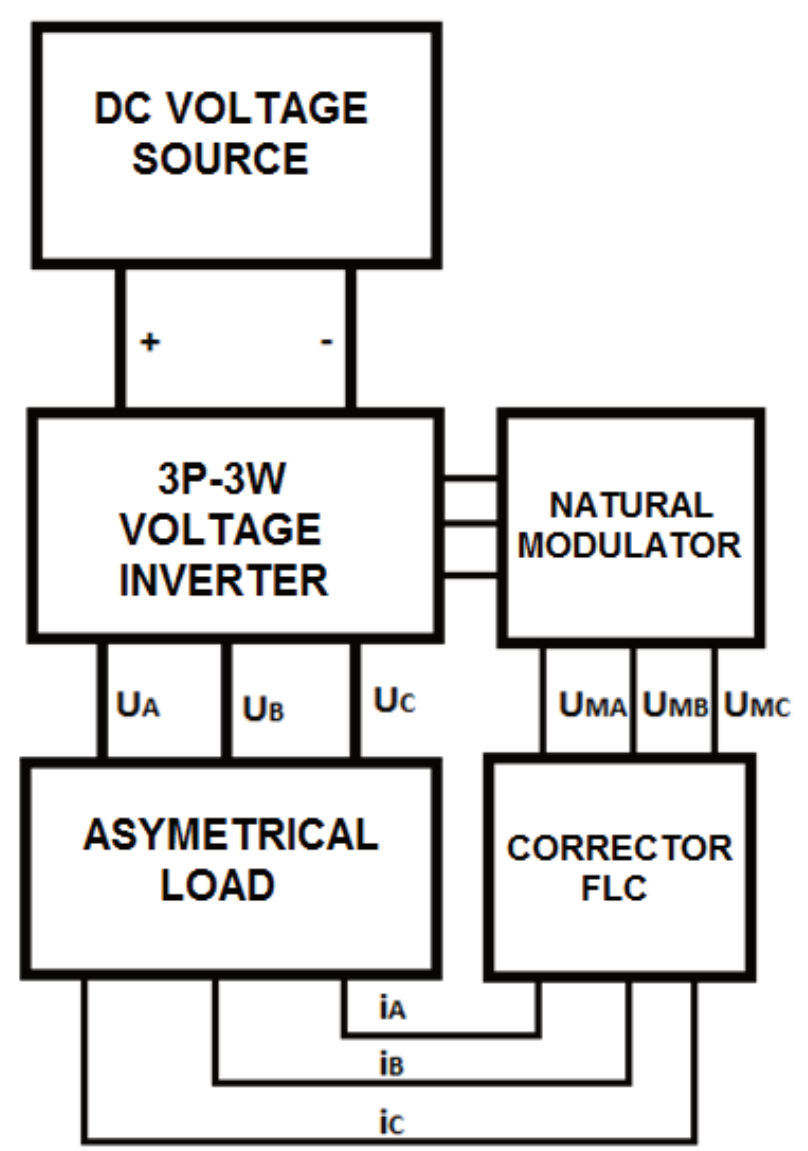

Fig. 1. Flowchart tracking the corrector in the control structure of the voltage inverter

Rys.1. Schemat blokowy lokalizujący układ korektora w strukturze sterowania falownikiem napięcia 
The voltage inverter block $3 \mathrm{P}-3 \mathrm{~W}$ in figure 1 represents a three-phase, three-wire voltage inverter which consists of six IGBT transistors connected as a typical bridge topology. This topology is considered in many studies. Modulated voltages UA, UB, UC are on load connectors. Block named ,asymmetrical load", shown in figure 1 , is the three phase load, which can be changed by parameterization. These changes relate to setting a different, asymmetric resistance values and inductance. Consequently, the load currents iA, iB, iC are unbalanced. In addition, the test stand allows the injection of no harmonic load changes. These changes are taken into account in the form of the total load and taken into account in the form of a block. The voltage modulator block represents a three-phase modulator with phase-modulating functions compared with a $5 \mathrm{kHz}$ triangular current waves. Sinusoidal modulation functions are adjusted in an active mode by corrector block in relation to current trajectory deformation. The FLC corrector is described using the fuzzy logic equations. The correction affects the scale of modulating function (UMA, UMB, UMC) influencing the modulator block working in a natural coordinate system.

\section{Fuzzy corrector of SV}

Changes of the space vector (SV) output currents of the 3-wire voltage inverter can be determined, (for example, a constant asymmetric load), or be random, (for example may arise from momentary disturbances or variable load nonlinearities). It is hard to define the influence, that corrector system must limit. In similar situations the systems are often described by the fuzzy logic equations.

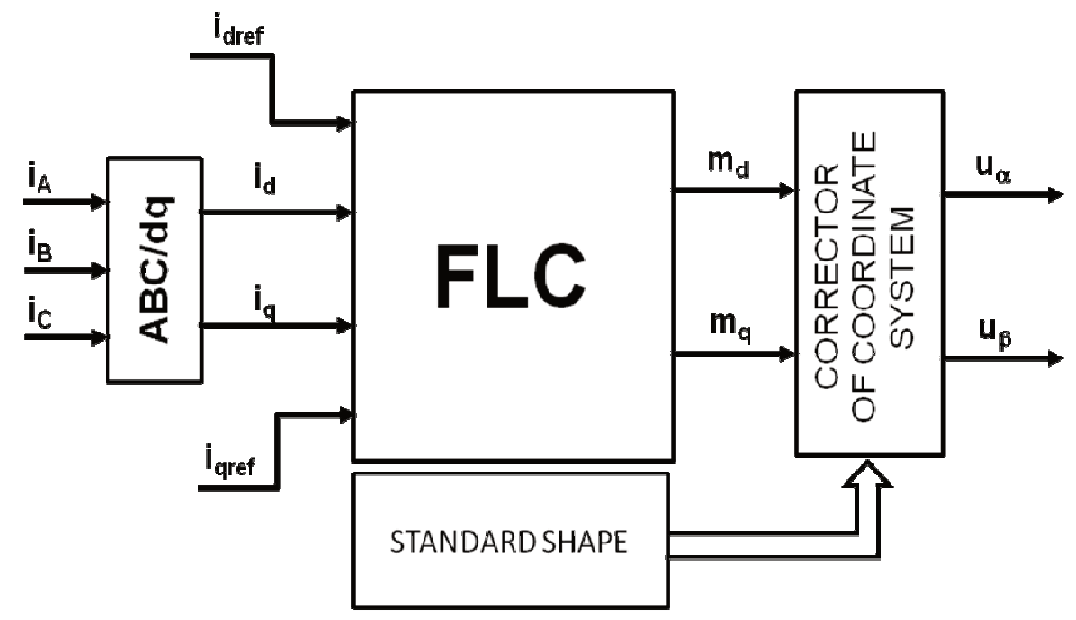

Fig. 2. Flowchart of the fuzzy corrector

Rys.2. Schemat blokowy układu korektora rozmytego 
These equations use an expert knowledge of the nature as the fuzzy sets, which are sharpened to the numerical form used in the process of correcting the modulation waves. Achieving the sinusoidal waveform of the output currents of 3 -phase voltage inverter at asymmetry load is possible by analyzing the space vector in the rotating coordinate system $d$-q. The rotating coordinate system is synchronized with the coordinate system associated with modulation functions of voltage. Changes of the vector currents coordinates in the d-q surface testify present derogations from the circular trajectory. In such a situation the coordinate system is corrected by temporarily changing its rotational speed that corrects changes in the currents hodograph. Value of the adjustment of the d-q is made based on the requesting module defined by fuzzy logic equations. Input of the FLC module consists of four signals. These are the values of the two displacement vector components of current and two values of the displacement coordinates changes of d-q current vector. In response to these four fuzzy signals, using singleton function, database corresponds to the rules defined in the form of two sets resulting from the implications of the Mamdani function. These sets are emphasized by calculating their centers of gravity and they are used in the corrections of $\mathrm{d}$ and $\mathrm{q}$ components of the modulating vector. Fuzzy sets representing correction rules have been determined as linguistic reasons described as follows:

P1 - decrease when too large,

$\mathrm{P} 2$ - increase, if too small,

P3 - do nothing when it is appropriate.

The premises were used for the $\mathrm{d}$ and q components in the same way for error and error change of currents. Fuzzy sets have been adopted in the form of triangular sets. Details describing the action of knowledge base, such as fuzzy sets and equations have been described in the literature [8]. The difference lies in the application of the similar response, as described in the correction of the no sinusoidal output currents [8], for two current components at the same time.

\section{Laboratory tests}

Presented concept of the space vector trajectory corrector of an output currents of the $3 \mathrm{P}-3 \mathrm{~W}$ voltage inverter was conducted and tested using the programmable logic device of the Altera Stratix III family. The inverter control unit, defined in VHDL language, leads a control data stream in one of two ports. One of the ports matches the physical port, which is connected to an external voltage inverter. The second port redirects the output from the control system to the digital model of the inverter and is launched in real time on the same programmable FPGA chip. The results presented in the article refer only to situations in which waves were observed based on the digital inverter model. For the card containing the programmable FPGA the module that includes fast ana- 
logue-to-digital converters and digital-to-analog converters was connected. The $\mathrm{A} / \mathrm{D}$ and $\mathrm{D} / \mathrm{A}$ were allocated to the currents measurement in the physical, external voltage inverter and allocated to send an analogue values of currents or voltages of the digital inverter model that runs in real time. The complexity of the calculations of the requesting module is large enough that, in order to facilitate the calculation processes analyzed space has been discredited and saved in the memory as a block representing a transition space. The coordinates of this space correspond to the discrete values of error and error changes of the vector component and heightened the value of the response of the deductive module. RAM that stores the transition space includes answers of module, which were addressed by a word containing in a less significant part the discrete value of the vector error and in a more significant part the discrete value of the error changes.

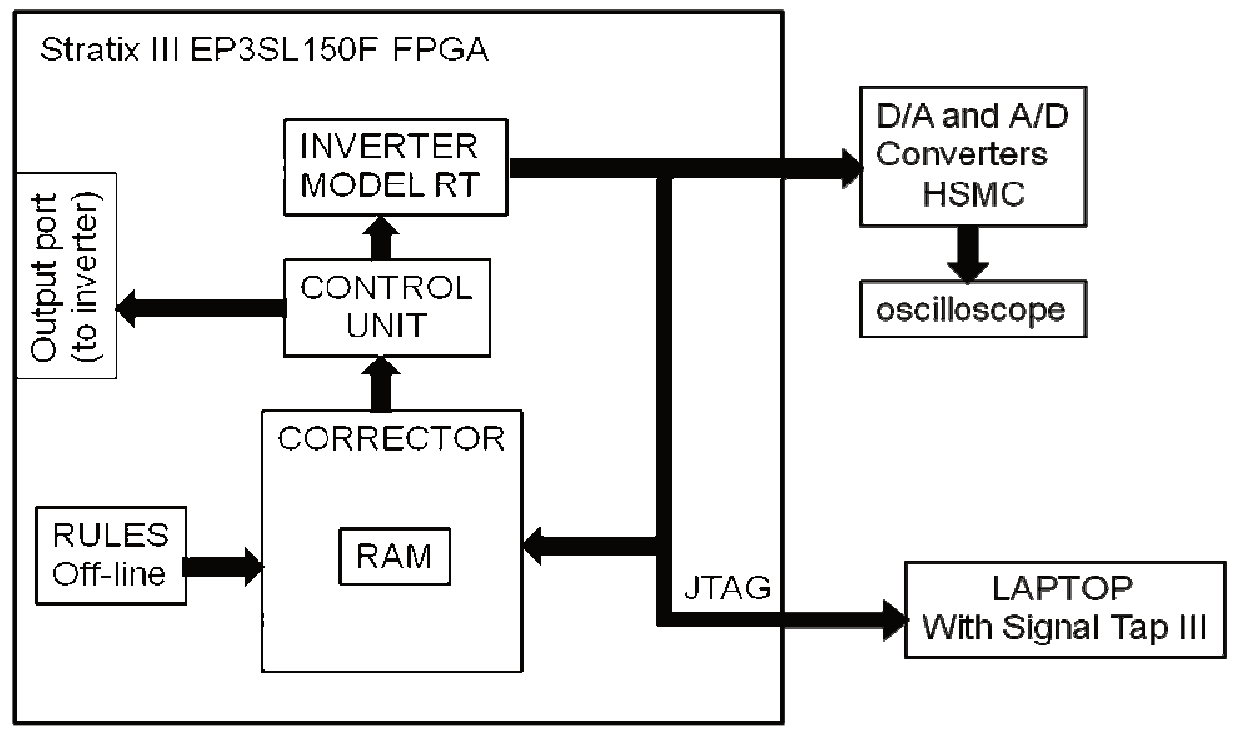

Fig. 3. A block diagram of the test bench

Rys.3. Schemat blokowy stanowiska badawczego

Laboratory tests verifying the concept of space vector trajectory of the inverter output current were conducted with the use of the digital voltage inverter model that runs in real time, on the same FPGA parallel with the control system. Digital signals representing the phase voltage and inverter output currents were observed in two ways. In the first case, these signals, when converted to analog form, were observed using an oscilloscope. At the same time, you can watch them on your computer screen via the JTAG interface cooperated with the tool Signal Tap II as a part of the Quartus II environment. This project was executed in this environment, and it configured the FPGA system. The performed tests 
include the asymmetry of a load: resistant, induction and a variable load asymmetry which emulate mechanical vibration of a quasi-stationary engine model.

Case 1: $\mathrm{R}_{1}=1 \Omega, \mathrm{R}_{2}=2 \Omega, \mathrm{R}_{3}=3 \Omega, \mathrm{L}=5 \mathrm{mH}$,

Case 2: $\mathrm{R}=1 \Omega, \mathrm{L}_{1}=1 \mathrm{mH}, \mathrm{L}_{2}=5 \mathrm{mH}, \mathrm{L}_{3}=10 \mathrm{mH}$,

Case 3: $\mathrm{R}=1 \Omega, \mathrm{L}_{1}=1 \mathrm{mH}, \mathrm{L}_{2}=5 \mathrm{mH}, \mathrm{L}_{3}=10 \mathrm{mH}$ with no-harmonic distortions.

In test cases, when the corrector was in off position, the space vector trajectories of load currents were an elliptical curves. A sample trajectory of a induction asymmetry is shown in figure 4 .

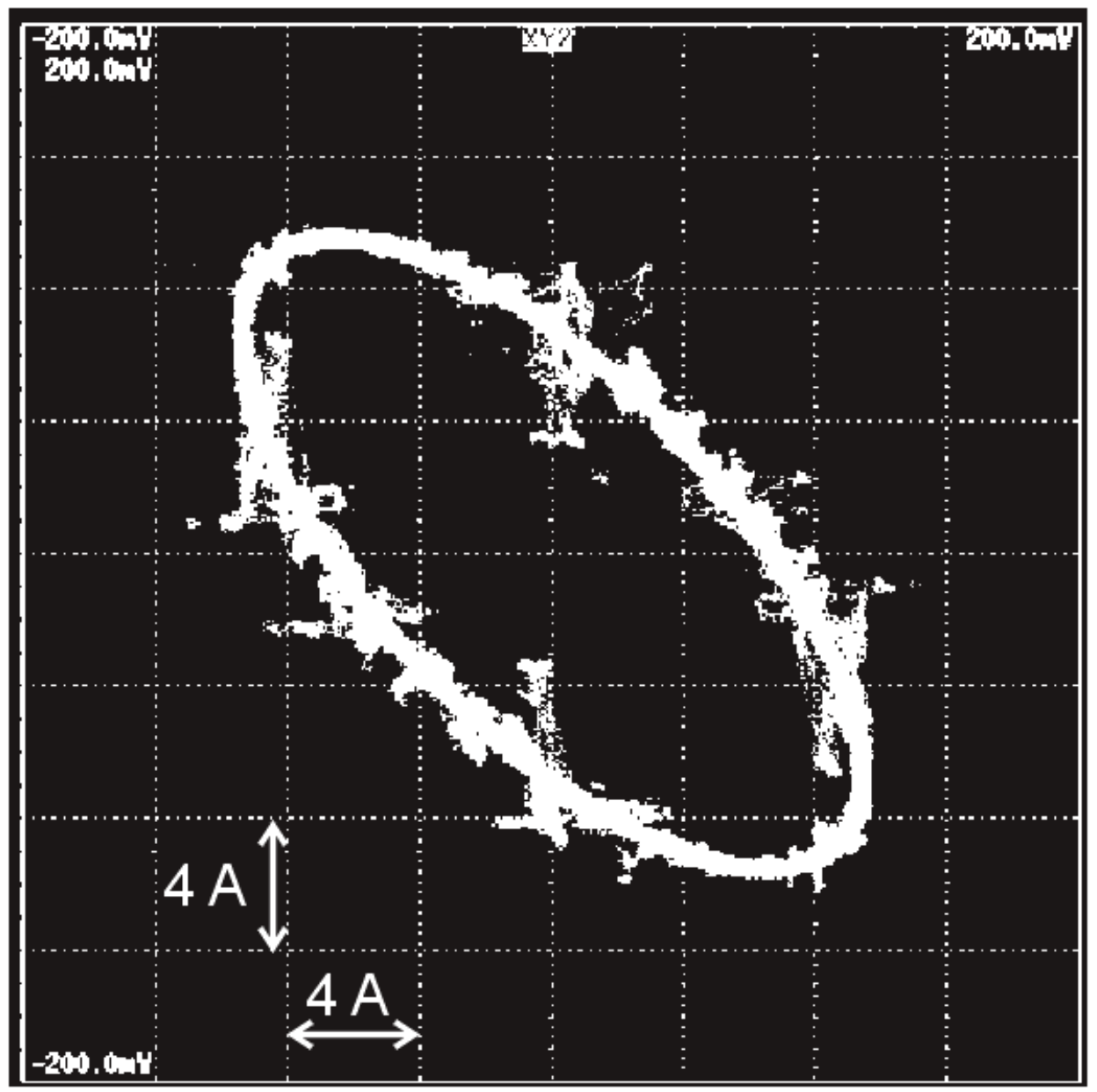

Fig. 4. Hodograph of the inverter output currents for a load in case of a induction asymmetry

Rys.4. Hodograf prądów wyjściowych falownika dla przypadku asymetrii indukcyjnej obciążenia

In case of an imposed no-harmonic deformations this path changed its position in time with a frequency of $60 \mathrm{~Hz}$ and the relative amplitude 0.3 . The test 
cases were for the primary component of the voltage with a frequency of $50 \mathrm{~Hz}$. An example of a trajectory in case of the induction asymmetry of load and imposed no-harmonic deformation is shown in figure 5.

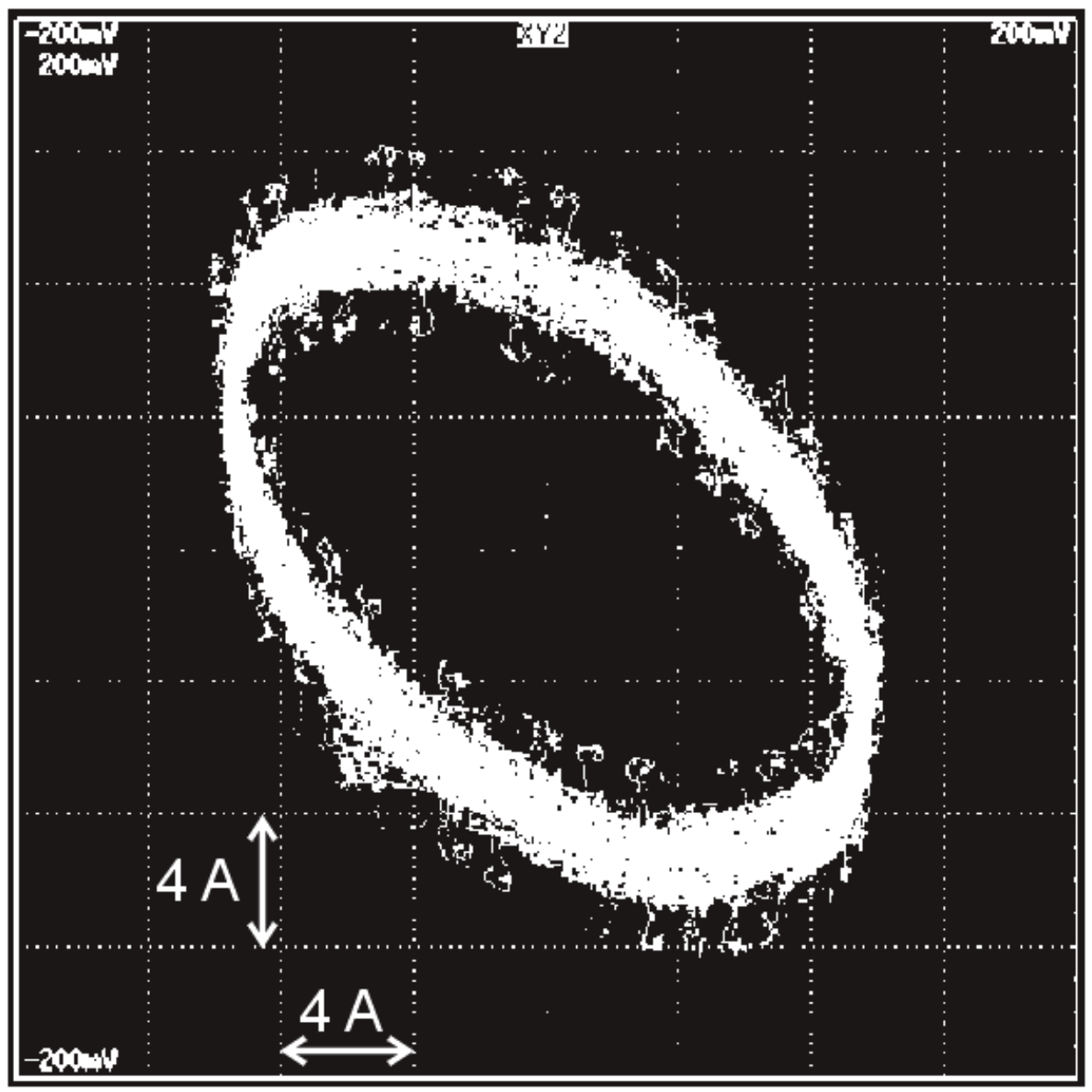

Fig. 5. Hodograph of the inverter output currents for a load in case of a induction asymmetry and no-harmonic distortions

Rys.5. Hodograf prądów wyjściowych falownika dla przypadku asymetrii indukcyjnej obciążenia i odkształceń nieharmonicznych

In case of a resistant or induction asymmetry the load currents are sinusoidal. Effect of asymmetry is visible in the form of different amplitudes of currents flowing in three phases of a load. In case of a no-harmonic component in currents their amplitude have evolved over time. An example of load currents in case of a resistant asymmetry is shown in figure 6 . 


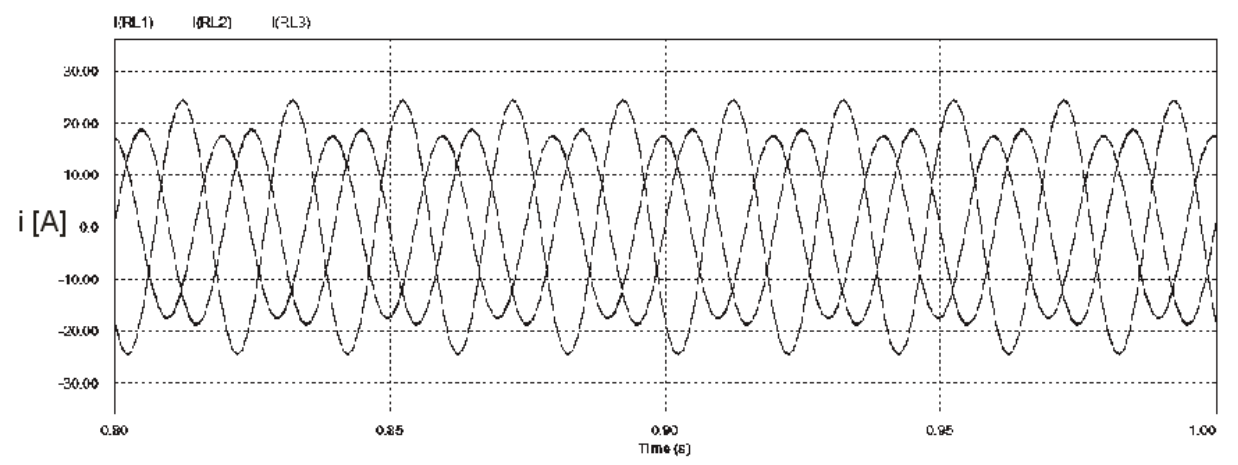

Fig. 6. Waveforms of currents for the case of resistant load asymmetry

Rys.6. Przebiegi prądów obciążenia dla przypadku asymetrii rezystancyjnej obciążenia

After joining the fuzzy corrector to a control process the circular trajectory of an output currents was obtained with given vector output currents equal to $10 \mathrm{~A}$. Example of the trajectory obtained after correcting effect of asymmetry is shown in figure 8. The load currents in case of an active process of space vector trajectory corrections, regardless of the type of deformation, were characterized by constant amplitude and a referenced shape. In the considered case the shape was sinusoidal. Example waveforms for a given amplitude 10A is shown in figure 7.

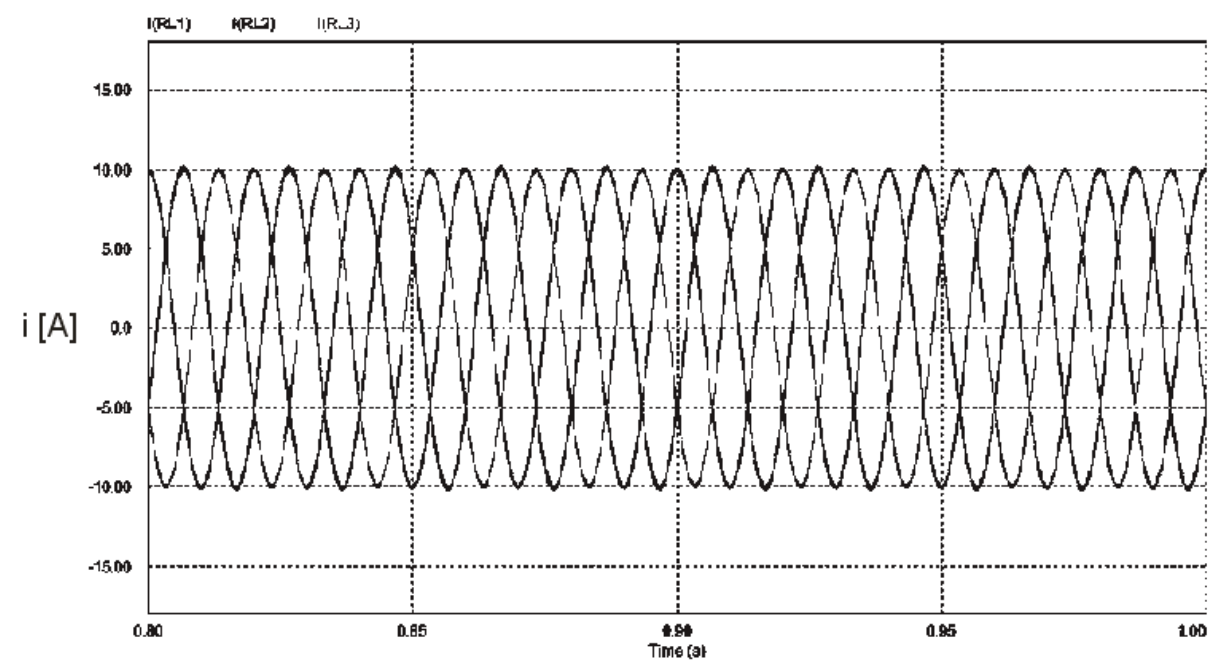

Fig. 7. The load currents when the corrector is on (asymmetrical load)

Rys.7. Przebiegi prądów obciążenia przy włączonym korektorze (asymetryczne obciążenie) 


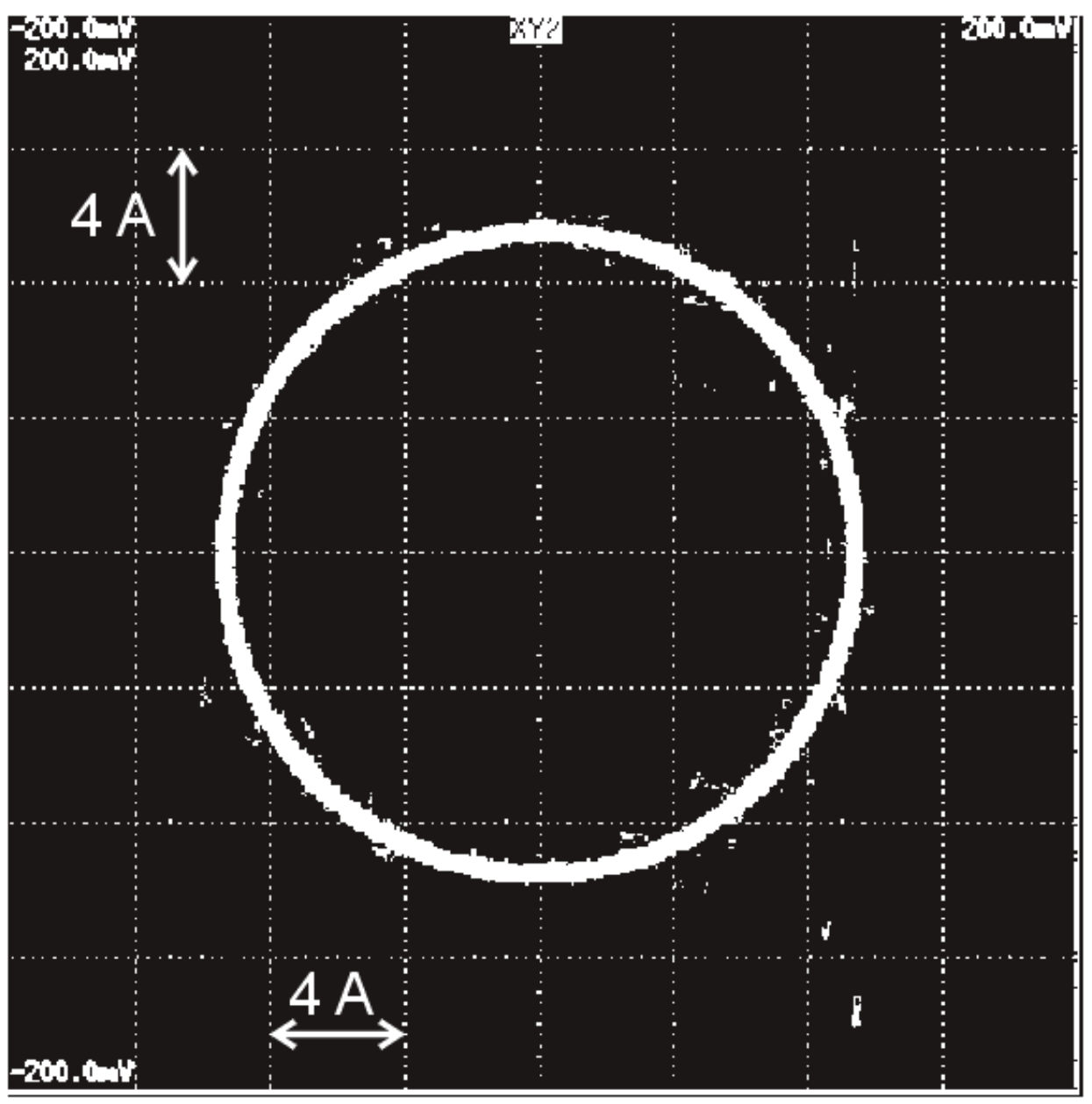

Fig. 8. Hodograph of the inverter output currents in case of the induction asymmetry of load with no-harmonic distortions when the corrector is turned-on

Rys.8. Hodograf prądów wyjściowych falownika przy asymetrii indukcyjnej obciążenia z nałożonymi odkształceniami nieharmonicznymi w przypadku włączonego korektora

\section{Conclusions}

A developed corrector of an output voltage inverter currents SV trajectory is described in the rotating coordinate system. This allows to set the shape of the output currents by attaching to the transformation block the proper wave with referencing shape. In the case of the electrical circuits it is sinusoidal shape, which forces the sinusoidal output current. Attaching the corrector to control process effects the sinusoidal load currents and causes a circular trajectory in 
cases of asymmetry of load and external factors. As a consequence, the solution containing the fuzzy inference shall be replaced by the first step of the current regulation as presented in the article. Reference values given by the inference module may come from a higher level of the control process, for example, speed regulator in the electric motor or voltage regulator. Laboratory tests carried out on a digital voltage inverter model operating in real time on the same hardware platform as the control system positively verify a concept and allow redirecting control data stream on the physical layout of the inverter.

\section{Literatura}

[1] Karimi R., Koeneke T., Kaczorowski D., Werner T. ; Mertens A.: Low voltage and high power DC-AC inverter topologies for electric vehicles, Energy Conversion Congress and Exposition (ECCE), 2013 IEEE

[2] Saren H., Pyrhonen O, Rauma K., Laakkonen O.; Overmodulation in Voltage Source Inverter with Small DC-link Capacitor, Power Electronics Specialists Conference, 2005, PESC '05.

[3] Kai Cai, Shanmei Cheng; A general SVM strategy for n-level m-phase converter based on voltage level, Industrial Electronics, 2008. IECON 2008. 34th Annual Conference of IEEE

[4] Szostek K.: Projektowanie procesora sekwencyjnego i symulacja w środowisku MATLAB/Simulink, Pomiary Automatyka Kontrola, vol. 59, NR 10/2013, str. 10611063, ISSN 0032-4140

[5] Szostek K.: Konstruowanie automatów sekwencyjnych w środowisku Matlab Simulink, Przegląd Elektrotechniczny, R. 90 NR 1/2014, str. 119-121, ISSN 0033-2097

[6] Szostek R.: Modelowanie systemów współbieżnych za pomocą sieci kolejkowych, Zeszyty Naukowe Politechniki Rzeszowskiej nr 245, z. 11, Rzeszów 2007, str. 153165

[7] Vinay, K.C. ; Shyam, H.N. ; Rishi, S. ; Moorthi, S., FPGA Based Implementation of Variable-Voltage Variable-Frequency Controller for a Three Phase Induction Motor, 2011 International Conference on Process Automation, Control and Computing, PACC 2011, 20-22, July 2011, Coimbatore, India

[8] Binkowski T., Korekcja trajektorii wektora przestrzennego z wykorzystaniem logiki rozmytej, Elektronika, nr 12/2012, ISSN 0033-2089, str. 35-38

\section{BADANIA KOREKCJI WEKTORA PRZESTRZENNEGO PRĄDÓW FALOWNIKA NAPIĘCIA 3P-3W}

\section{Streszczenie}

Artykuł przedstawia rozwiązanie problemu asymetrii prądów wyjściowych trójfazowego falownika napięcia polegające na korekcji trajektorii wektora prądów do postaci kołowej. Przedstawione rozwiązanie wykorzystuje układ opisany równaniami logiki rozmytej. Wyniki badań dotyczą sprawdzenia działania układu w warunkach asymetrycznego obciążenia. Sprawdzono postać kołową trajektorii wektora prądów wyjściowych w przypadku asymetrii rezystancyjnej lub induk- 
cyjnej obciążenia. Wprowadzono także do obciążenia odkształcenia prądów nie będące składowymi harmonicznymi, które symulują drgania części mechanicznej obciążenia lub rezonans mechaniczny. Po weryfikacji idei symulacjami wykonano prototyp laboratoryjny układu sterowania falownikiem z korektorem w układzie FPGA.

Badania wykonano na stworzonym do tego celu stanowisku badawczym wykorzystującym układ EP3SL150F. Układ ten realizował zadanie korekcji wektora przestrzennego prądów falownika i jednocześnie proces modulacji przebiegów. Równolegle z zadaniami sterowanie uruchomiony był model falownika działający w czasie rzeczywistym. Przebiegi modelu falownika obserwowano wykorzystując narzędzie Signal Tap II lub po przetworzeniu na sygnał analogowy przy pomocy oscyloskopu. Zaobserwowane trajektorie wektora przestrzennego prądów korygowane były do postaci kołowej niezależnie od rodzaju asymetrii obciążenia.

Słowa kluczowe: wektor przestrzenny, falownik napięcia, korektor, logika rozmyta

DOI: $10.7862 /$ re.2015.9

Tekst zlożono $w$ redakcji: luty 2015

Przyjęto do druku: kwiecień 2015 